\title{
Vapaan sivistystyön juhlavuosi
}

Kaikilla keskeisimmillä vapaan sivistystyön organisaatiomuodoilla on ollut tänä vuonna omat merkkipäivänsä ja juhlansa. Kansanopistoliike juhli marraskuussa 100-vuotistaivaltaan, sillä maamme ensimmäinen kansanopisto perustettiin Kangasalle vuonna 1899. Ville Marjomäki tarkastelee artikkelissaan "Kansanopistoliike ja yhteiskunnallinen muutos" kansanopistoliikkeen kehitystä toiminnan alkuajoista näihin päiviin asti. Kansanopistojen aatemaailma on hänen mukaansa aina kytkeytynyt kansanliikkeiden ja vähemmistökulttuurien kohtaloihin. Kansanopistojen suhde valtiovaltaan on ollut kaikkina aikoina jossain määrin ongelmallinen, joskin eri aikoina hiukan eri syistä. Marjomäen mukaan kansanopistoissa on nykyisin tiedostettu se jännite, joka aina pakostakin vallitsee virallisen aseman ja arvostuksen sekä vapauden ja omaehtoista kriittisyyttä edustavan toiminnan välillä. Vaikka osalla kansanopistoista onkin tänä päivänä vaikeuksia, niin kokonaisuutena ne näyttävät onnistuneet melko hyvin omaehtoisessa tehtävänhaussaan. Kuvaavaa on, että kansanopistojen lukumäärä on jatkuvasti lisääntynyt. Tällä hetkellä niitä on jo 93 kappaletta. Opistojen peruskursseilla opiskelee vuosittain noin 6000 nuorta tai aikuista. Opistojen aikuisoppilaitosluonne on lisääntynyt lyhytkurssitoiminnan laajenemisen kautta. Niille osallistuu vuosittain noin 60000 aikuista.

Kansalaisopistoliikkeellä on ollut myös syytä juhlaan, jopa kahdesta eri syystä. Lokakuussa vietettiin samanaikaisesti opistotyön 90 -vuotis- sekä liiton (KTOL) 70-vuotisjuhlia. Kuten tunnettua maamme ensimmäinen työväenopisto perustettiin Tampereelle vuonna 1899. Professori Kosti Huuhka piti tilaisuudessa juhlapuheen, jossa hän tarkasteli opistoliikkeen kehitystä työväen opistoista koko kansan opistoiksi. Hänen puheensa julkaistaan tässä lehdessä. Huuhka erottaa opistoliikkeen kehityksessä kolme eri vaihetta: autonomian aikaa hän nimittää opistojen perustamisvaiheeksi, maailmansotien välistä aikakautta vakiintumisvaiheeksi ja toisen maailmansodan jälkeistä laajenemisvaiheeksi. Melkoisen laajaksi opistoliike onkin paisunut, sillä nykyisin meillä on 278 opistoa, joissa vuosittain opiskelee noin 600000 aikuista.

Myös järjestömuotoisella sivistystyöllä on ol- lut merkkivuosi, sillä maamme ensimmäinen sivistysjärjestö, Työväen Sivistysliitto, perustettiin 70 vuotta sitten, eli vuonna 1919. Jorma Turunen tarkastelee artikkelissaan "Työväen sivistystyö ja yhdentyvä Eurooppa" niitä ongelmia ja haasteita, joita Euroopan integraatiokehitys tuo mukanaan erityisesti työväen sivistystyölle. Seppo Ylinen puolestaan kertoo Työväen Sivistysliiton harjoittamasta kansainvälisyyskasvatuksesta ja Jussi Pikkusaari tilittää tuntojaan neljännesvuosisadan kestäneestä toiminnastaan työväen sivistystyön eri tehtävissä. Hänen mielestään järjestöllisen sivistystyön tukijoita on ollut aivan liian vähän. Erityisesti järjestöjen kulttuuritoiminnan tulisi Pikkusaaren mielestä saada lisää tukea, koska juuri kulttuuritoiminnassa toteutuu parhaiten sivistysjärjestöjen omaehtoinen luonne. Nykyisin meillä on kaikkiaan 11 opintokeskusta, jotka organisoivat kymmenien eri järjestöjen opintotoimintaa. Opintokeskusten opintokerho-, kurssi- ja opinto-ohjaajakoulutukseen osallistuu vuosittain lähes 400000 aikuista. Jos luentotoiminta lasketaan mukaan, niin opintokeskusten osallistujamäärä kohoaa noin 600 000:een. Vaikka otetaankin huomioon se, että samat henkilöt voivat esiintyä tilastoissa useampaan kertaan, niin joka tapauksessa opintokeskusten harjoittama opintotoiminta on nykyisin varsin laajaa.

Edellämainittujen lisäksi on syytä todeta joitakin muitakin merkkivuositapahtumia. Vapaan sivistystyön yhteisjärjestön perustamisesta samoin kuin Yleisradion aikuisopetuksen aloittamisesta tulee tänä vuonna kuluneeksi 20 vuotta. Asianomaiset tahot juhlivat merkkipäiviään marraskuun lopulla. Myös Oriveden opisto juhli joulukuussa 80-vuotistaivaltaan. En ole varma, onko edellä tullut mainittua edes kaikki ne vapaan sivistystyön organisaatiot, jotka tänä vuotta viettävät juhliaan. Joka tapauksessa voi liioittelematta sanoa, että kuluva vuosi on ollut eräänlainen vapaan sivistystyön juhlavuosi, joten jonkinlainen yhteisesiintyminenkin olisi ehkä ollut paikallaan. Erillisinä pidettävät juhlat - saamastaan julkisuudesta huolimatta - jäävät helposti laajimmilta väestöpiireiltä huomaamatta. Onko tämä vapaan sivistystyön eri toimintamuotojen "yksityistyminen" osoitus siitä, että vapaan sivistystyön peruslähtökohtia ja tavoitteita ei koeta enää siinä 
määrin yhteisiksi kuin aikaisemmin, eikä yhteisesiintymistä koeta tästä syystä tarpeellisena?

Toimintansa alkuaikoina keskeiset kansansivistysorganisaatiot olivat peruslähtökohdiltaan melko samankaltaisia. Sekä kansanopistojen, työväenopistojen että sivistysjärjestöjen kohderyhmänä oli lähinnä työväestö, niin kaupungeissa kuin maaseudullakin asuva, ja toiminnan tavoitteena oli sivistyksen levittäminen kansan keskuuteen. Nykyisin kaikkien organisaatiomuotojen kohderyhmät ovat laajentuneet niin, että niiden opiskelijat koostuvat lähes kaikista kansalaispiireistä. Myös maaseutukaupunki -jaottelu on menettänyt merkitystään, kun kansalaisopistot ovat laajentuneet maaseudulle ja kansanopistojen opiskelijoista suuri osa on kotoisin kaupungeista. Myös sivistysjärjestöjen toiminta tapahtuu sekä kaupungeissa että maaseudulla. Opintopalvelusten laajeneminen ja opiskelijarakenteen monipuolistuminen on tietysti hyvä asia, vaikka se on aiheuttanut myös joitakin ongelmia. Tällaisena on koettu mm. eri organisaatiomuotojen profiilin hämärtyminen ja keskinäisen kilpailun lisääntyminen. Näyttää kuitenkin siltä, että kaikille vapaan sivistystyön organisaatioille riittää kyllä tehtäviä ja että kullakin organisaatiomuodolla on omat erityispiirteensä, joiden pohjalta ne voivat edelleen kehittyä.

Kun vapaa sivistystyö on vakiinnuttanut asemansa suomalaisessa yhteiskunnassa, niin jotakin näyttää samalla unohtuneen. Meillä on keskusteltu viime aikoina melko vähän siitä, mitkä ovat vapaan sivistystyön tavoitteet ja tehtävät tämän päivän yhteiskunnassa? Mikä on se sivistyneen ihmisen ideaali, jonka edistämiseen sivistystyöllä pyritään? Missä määrin vapaan sivistystyön organisaatiot ovat autonomisia, itse tavoitteensa asettavia kansanliikkeitä vai onko niistä tullut vain muodollisen koulujärjestelmän jatke? Näistä ja monista muista peruskysymyksistä olisi syytä keskustella siitäkin huolimatta - tai oikeastaan juuri siitä syystä - että nykyinen koulutuspoliittinen keskustelu on yksipuolisesti kiinnostunut vain työelämää palvelevasta ammatillisesta koulutuksesta. Työelämää ja vapaata sivistystyötä ei ole kuitenkaan syytä asettaa vastakkain, sillä työelämän kehittäminen lisää epäilemättä ihmisten kiinnostusta myös vapaa-aikana tapahtuvaan omaehtoiseen opiskeluun. Koulutuspoliittisessa keskustelussa pitäisi ihmistä tarkastella kokonaisuutena. Hänellä on sekä työhön että muuhun yhteiskunta- ja yksityiselämäänsä liittyviä opiskelu- ja kehittymistarpeita. Näyttää siltä, että painopiste ihmisten ajattelussa on siirtymässä entistä enemmän viimeksimainittu- jen kehittymistarpeiden suuntaan. Tämän pitäisi näkyä paremmin myös koulutuspoliittisessa keskustelussa ja -suunnittelussa.

Ruotsalainen tutkija Lars Arvidson on julkaissut pienimuotoisen tutkielman "Kansansivistys tutkimusalueena", jossa hän kartoittaa kansansivistystyön tutkimusaluetta ja alan nykyisiä tutkimustarpeita. Kansansivistyksen tutkimuskohteen hän täsmentää tarkastelemalla kolmea keskeistä ydinkysymystä: kansansivistys tieteen popularisoijana, vapaan ja vapaaehtoisen kansansivistyksen olemus sekä kansansivistys itsekasvatuksena ja vastakulttuurina. Kaikessa kansansivistystä koskevassa keskustelussa täytyy hänen mielestään lähteä siitä, että kysymys on prosessista, jota ei saa rajata koskemaan vain nykyisiä kansansivistysorganisaatioita, vaan lähtökohdaksi on otettava koko "kansansivistystapahtuma" (folkbildningsskeende), joka voi käytännössä ilmetä monenlaisissa eri yhteyksissä. Olisiko meilläkin syytä pohtia laajemmin kansansivistystyön olemusta ja ilmenemismuotoja nykyisessä yhteiskunnallisessa tilanteessa? Arvidson esittää tutkielmassaan myös esimerkkejä alan tutkimustarpeista. Tutkimusta kaipaavia kysymyksiä ovat hänen mukaansa mm.: 1) missä yhteyksissä ja minkälaisissa muodoissa kansansivistys esiintyy, 2) minkälainen on kansansivistyksen edustajien sivistysnäkemys, 3) kansansivistyksen merkitys ajatellen demokratian ja yhteiskunnallisen osallistumisen edistämistä, 4) kansansivistyksen suhde ammattirakenteeseen ja ammatilliseen koulutukseen, 5) kansansivistyksen funktio aikuiskasvatuksen kokonaisuudessa, 6) kielen, kirjallisuuden ja taiteen rooli kansansivistyksessä, 7) osallistujatutkimus sekä 8) eri maiden kansansivistysjärjestelmien vertaileva tutkimus. Tutkimusaiheet tuntuvat relevanteilta myös suomalaisesta näkökulmasta tarkastellen. Ongelmana meillä on epäilemättä alaa tuntevien ja siitä kiinnostuneiden tutkijoiden vähäisyys. Näyttää myös siltä, että kansansivistystyön tutkimus ei ole tällä hetkellä tutkimusta rahoittavien tahojen suosiossa. Tähän täytyisi saada muutos. Voi tietysti myös kysyä, ovatko edes vapaan sivistystyön keskusjärjestöjen edustajat ymmärtäneet riittävästi alan tutkimuksen merkitystä oman työnsä kehittämisessä. Kun juhlavuoden pöly alkaa vähitellen laskeutua, voisivat asianomaiset viranomaiset ja alan keskusjärjestöt ryhtyä yhdessä pohtimaan, mitä alan tutkimuksen edistämiseksi voitaisiin tehdä.

Jukka Tuomisto 